\title{
Phosphorus Fractionation in Soil Cultivated with Sugarcane Fertilized by Filter Cake and Phosphate Sources
}

\author{
Gustavo Caione, Renato de Mello Prado, Cid Naudi Silva Campos, Marcos \\ Rodrigues, Paulo Sérgio Pavinato \& Flávia Bastos Agostinho
}

To cite this article: Gustavo Caione, Renato de Mello Prado, Cid Naudi Silva Campos, Marcos Rodrigues, Paulo Sérgio Pavinato \& Flávia Bastos Agostinho (2015) Phosphorus Fractionation in Soil Cultivated with Sugarcane Fertilized by Filter Cake and Phosphate Sources, Communications in Soil Science and Plant Analysis, 46:19, 2449-2459, DOI: 10.1080/00103624.2015.1081926

To link to this article: https://doi.org/10.1080/00103624.2015.1081926

Aug 2015.

Published online: 26 Oct 2015.

Submit your article to this journal $\pi$

Џll Article views: 145

View Crossmark data ¿

Citing articles: 2 View citing articles 지 


\title{
Phosphorus Fractionation in Soil Cultivated with Sugarcane Fertilized by Filter Cake and Phosphate Sources
}

\author{
GUSTAVO CAIONE, ${ }^{1}$ RENATO DE MELLO PRADO, ${ }^{1}$ CID \\ NAUDI SILVA CAMPOS, ${ }^{1}$ MARCOS RODRIGUES, ${ }^{2}$ PAULO \\ SÉRGIO PAVINATO, ${ }^{2}$ AND FLÁVIA BASTOS AGOSTINHO ${ }^{3}$ \\ ${ }^{1}$ Department of Soils and Fertilizers, Sao Paulo State University UNESP, \\ Jaboticabal, SP, Brazil \\ ${ }^{2}$ University of São Paulo, "Luiz de Queiroz" College of Agriculture, Soil Science \\ Department, Piracicaba, SP, Brazil \\ ${ }^{3}$ Louisiana State University, School of Plant, Environmental and Soil Sciences, \\ Baton Rouge, Louisiana, USA
}

\begin{abstract}
Studies of phosphorus $(P)$ forms in high-weathering soils, after long periods of phosphate fertilizer application associated with organic residues, are important to optimize P fertilization. This study aims to evaluate the effect of filter cake application and other distinct phosphate sources on organic and inorganic $P$ fractions in Red Eutrophic Argisoil cultivated with sugarcane. The experiment was established between 2012 and 2014, in Sao Paulo State, Brazil. The treatments were as follows: control (without P), triple superphosphate, natural phosphate from Araxá, and naturally reactive phosphate Bayóvar on the presence and absence of filter cake at $7.5 \mathrm{th} \mathrm{h}^{-1}$ (dry mass). The P rate was $90 \mathrm{~kg} \mathrm{ha} a^{-1}$ of phosphorus pentoxide $\left(\mathrm{P}_{2} \mathrm{O}_{5}\right)$ soluble in citric acid. The experiment was arranged in a randomized block, in $a 4 \times 2$ factorial with three repetitions. After 22 months of treatments, soil samples were collected on sugarcane planting lines and $P$ fractionation was analyzed. The greatest percentage of $P$ is found as nonlabile $P$ fractions, regardless of filter cake application or not. The use of low solubility sources, such as natural phosphate from Araxá, in association with filter cake has promoted greater solubility of $P$ bound to calcium (Ca), which can enhance the crop uses. Filter cake increases most of labile and moderately labile inorganic $P$ forms in the soil (resin; sodium bicarbonate, $\mathrm{NaHCO}_{3}$; and sodium hydroxide, $\mathrm{NaOH}, 0.1 \mathrm{~mol} \mathrm{~L}^{-1}$ ), which characterizes the importance of this source to sugarcane nutrient supply.
\end{abstract}

Keywords Organic residue, phosphorus forms, phosphorus sources, residual effect

\section{Introduction}

Phosphorus (P) deficiency is a worldwide barrier to plants growth (Khan and Joergensen 2009), holding greater significance in tropical soils, because they have low P availability due to adsorption and precipitation processes. Because $\mathrm{P}$ is the second nutrient that most

Received 14 October 2014; accepted 27 May 2015

Address correspondence to Gustavo Caione, Department of Agronomy, UNEMAT - Mato Grosso State University, Rodovia MT 208, km 147, Bairro Jardim Tropical, S/N. CEP: 78580-000, Alta Floresta, MT, Brazil. E-mail: gcaione@unemat.br 
limits crop yields (Biswas and Narayanasamy 2006), in case of soil deficiency its availability can be increased by organic and inorganic fertilizer application (Ayaga, Todd, and Brookes 2006). However, 85 to $90 \%$ of $\mathrm{P}$ added to soil is not available to plants in the first year of application, due to its adsorption and precipitation by iron $(\mathrm{Fe})$, aluminium $(\mathrm{Al})$, and calcium (Ca) bindings (Gichangi, Mnkeni, and Brookes 2009), which creates P storage in the soil called residual (Gikonyo et al. 2008).

The application of distinct phosphate fertilizers results in different soil $\mathrm{P}$ fraction accumulations, which mainly depend on rate, crop removal, soil mineralogy, climatic conditions (Schmitt, Buol, and Kamprath 1996), and period of contact. In doing so, the study of P sources with different solubility is important (Meena 2010) to better understand this nutrient behavior on the wide conditions and uses of agricultural soils, especially on tropical regions.

Soil $\mathrm{P}$ forms are distributed according to the ligant chemical nature and the binding energy between nutrient and soil. Regarding the ligand nature, $\mathrm{P}$ can be found as both organic and inorganic forms bound to $\mathrm{Fe}, \mathrm{Al}, \mathrm{Ca}$, silicate clays, and $\mathrm{Fe}$ and $\mathrm{Al}$ oxides. Thereby, the $\mathrm{P}$ forms found in the soil have different capacities of desorption and nutrient reposition to soil solution, according to its chemical nature and binding energy (Souza Jr. et al. 2012).

Soil P fractionation is an important technique to identify the dynamic of nutrient's transformation in the soil (Silva and Raij 1996), and it has been a good way to understand total $\mathrm{P}$ availability in the soil as well as its solubility. Because of this, the technique has become useful to study soil nutrient dynamics under different management systems (Pavinato, Merlin, and Rosolem 2009) and different phosphate fertilization via varied solubility sources.

After long periods of phosphate fertilization, different residual fractions are accumulated in the soil, with distinct degrees of binding energy (Negassa and Leinweber 2009; Linquist, Ruark, and Hill 2011; Tokura et al. 2011). There is evidence of a synergic effect between phosphate fertilizer and organic compost applications, which increases the content of available P in the soil (Mkhabela and Warman 2005; Ohno et al. 2005; Garg and Bahl 2008), and consequently reduces the mineral fertilizer rate.

The presence of organic compost, such as filter cake, in association with mineral fertilizer might increment labile P fractions of the soil; however, this effect is dependent on fertilizer source, as Almeida Jr. et al. (2011) reported that filter cake corrects acidic soils and, in this condition, natural phosphates would have lower P labile fractions due to its lower solubility on high $\mathrm{pH}$.

It is relevant to emphasize that studies regarding this issue are recent in Brazil, which is a reason to worry, as soil $\mathrm{P}$ knowledge is necessary to optimize the use of phosphate fertilization on sustainable bases. Therefore, this study aims to evaluate the effect of filter cake application and other distinct phosphate sources on organic and inorganic P fractions, in Red Eutrophic Argisoil cultivated with sugarcane.

\section{Material and Methods}

The experiment took place at Catanduva, São Paulo State, Brazil ( $21^{\circ} 05^{\prime} 07^{\prime \prime} \mathrm{S}, 48^{\circ}$ $54^{\prime} 22^{\prime \prime} \mathrm{O}$, altitude of $550 \mathrm{~m}$ ), in a Red Eutrophic Argisoil (Santos et al. 2013). Before planting, 20 soil subsamples were taken at $0.0-0.20 \mathrm{~cm}$ deep, which were used for fertility chemical analyses, according to the methodology described by Raij et al. (2001). The soil tested showed the following chemical characteristics: $\mathrm{pH}$ calcium chloride $\left(\mathrm{CaCl}_{2}\right)=5.5$; organic matter $=12 \mathrm{~g} \mathrm{dm}^{-3} ; \mathrm{P}$ (resin) $=5 \mathrm{mg} \mathrm{dm}^{-3}$; 
$\mathrm{K}^{+}=3.1 \mathrm{mmol}_{\mathrm{c}} \mathrm{dm}^{-3} ; \mathrm{Ca}^{2+}=30 \mathrm{mmol}_{\mathrm{c}} \mathrm{dm}^{-3} ; \mathrm{Mg}^{2+}=13 \mathrm{mmol}_{\mathrm{c}} \mathrm{dm}^{-3} ; \mathrm{H}^{+}+\mathrm{Al}^{3}$

${ }^{+}=18 \mathrm{mmol}_{\mathrm{c}} \mathrm{dm}^{-3}$; cation exchange capacity $=64 \mathrm{mmol}_{\mathrm{c}} \mathrm{dm}^{-3}$; and base saturation $=72 \%$. Acidic correction was not needed as base saturation was in an accepted range for the crop, according to the regional recommendations (Raij and Cantarella 1997).

Phosphate fertilizers were applied in May 2012 and sugarcane planting was placed afterward. Eight treatments were evaluated: control (without P), triple superphosphate ( $44 \%$ of total $\mathrm{P}_{2} \mathrm{O}_{5}$ and $41 \%$ soluble in $2 \%$ citric acid), natural phosphate from Araxá ( $22 \%$ of total $\mathrm{P}_{2} \mathrm{O}_{5}$ and $4 \%$ soluble in $2 \%$ citric acid), and naturally reactive phosphate Bayóvar (28\% of total $\mathrm{P}_{2} \mathrm{O}_{5}$ and $14 \%$ soluble in $2 \%$ citric acid), in the presence and absence of filter cake at $7.5 \mathrm{t} \mathrm{ha}^{-1}$ (dry mass). The experiment was arranged in a randomized block in a $4 \times 2$ factorial with three repetitions. Each experimental unit was composed of 5 rows, $15 \mathrm{~m}$ long and separated by $1.5 \mathrm{~m}$. The evaluations were taken on the three central rows, discarding $1 \mathrm{~m}$ of each tip.

Every $\mathrm{P}$ application followed the rate of $90 \mathrm{~kg} \mathrm{ha}^{-1}$ of $\mathrm{P}_{2} \mathrm{O}_{5}$ soluble in citric acid. To verify the possibility of reduction on mineral fertilizer rate when filter cake is present, it used $50 \%$ of the recommended rate stated by Raij and Cantarella (1997), as greater efficiency of plant $\mathrm{P}$ uptake is obtained when organic composts are associated with fertilizers.

Filter cake was submitted to composting and, before its application, chemical analysis following Bataglia et al.'s (1983) methodology was done. The values obtained are expressed below as a dry mass at $60-65^{\circ} \mathrm{C}: \mathrm{N}=14.0 \mathrm{~g} \mathrm{~kg}^{-1} ; \mathrm{P}=9.2 \mathrm{~g} \mathrm{~kg}^{-1}$; $\mathrm{K}=3.4 \mathrm{~g} \mathrm{~kg}^{-1} ; \mathrm{Ca}=25.3 \mathrm{~g} \mathrm{~kg}^{-1} ; \mathrm{Mg}=9.0 \mathrm{~g} \mathrm{~kg}^{-1} ; \mathrm{S}=3.3 \mathrm{~g} \mathrm{~kg}^{-1}$; boron (B) $16 \mathrm{mg} \mathrm{kg}{ }^{-1}$; copper $(\mathrm{Cu})=43 \mathrm{mg} \mathrm{kg}^{-1} ; \mathrm{Fe}=9.374 \mathrm{mg} \mathrm{kg}^{-1}$; manganese $(\mathrm{Mn})=753 \mathrm{mg} \mathrm{kg}^{-1}$; and zinc $(\mathrm{Zn})=70 \mathrm{mg} \mathrm{kg}^{-1}$.

The fertilizer applications were placed at the bottom of planting furrow (about 0.25 to $0.30 \mathrm{~m}$ deep). Subsequently, CTC 15 sugarcane seedlings were distributed and covered by a 0.10 - to $0.15-\mathrm{m}$ layer of soil. Nitrogen fertilization was also applied 40 days after planting, at the rate of $50 \mathrm{~kg} \mathrm{ha}^{-1}$ (ammonium nitrate). In the second year of cultivation (2013), fertilization was done according to sugarcane recommendations (Raij and Cantarella 1997), which provides $120 \mathrm{~kg} \mathrm{ha}^{-1}$ of $\mathrm{N}$ and $120 \mathrm{~kg} \mathrm{ha}^{-1}$ of potassium oxide $\left(\mathrm{K}_{2} \mathrm{O}\right)$, via ammonium nitrate and potassium chloride, respectively.

After 22 months of phosphate treatments applications, soil samples were collected on sugarcane planting lines (expected place to have greater fertilizers concentration) at 0.0 $0.30 \mathrm{~m}$ deep. Soil samples were formed by mixing 20 subsamples, which were taken on central plant lines of each experimental unit. According to Hedley, Stewart, and Chauhan's (1982) methodology and to the modifications by Condron, Goh, and Newman (1985), soil samples were submitted to fractionation of $\mathrm{P}$ forms.

The sequential extraction was as follows: anions exchange resin $[0.5 \mathrm{~g}$ of soil + $10 \mathrm{~mL}$ of water $\left(\mathrm{H}_{2} \mathrm{O}\right)+$ resin]; $10 \mathrm{~mL}$ of sodium bicarbonate $\left[\mathrm{NaHCO}_{3}\left(0.5 \mathrm{~mol} \mathrm{~L}{ }^{-1}\right)\right]$; $10 \mathrm{~mL}$ of sodium hydroxide $\left[\mathrm{NaOH}\left(0.1 \mathrm{~mol} \mathrm{~L}^{-1}\right)\right] ; 10 \mathrm{~mL}$ of hydrochloric acid $[\mathrm{HCl}$ $\left.\left(1 \mathrm{~mol} \mathrm{~L} \mathrm{~L}^{-1}\right)\right]$; $10 \mathrm{~mL}$ of $\mathrm{NaOH}\left(0.5 \mathrm{~mol} \mathrm{~L}^{-1}\right)$; and residual digestion with concentrated $\mathrm{H}_{2} \mathrm{SO}_{4}{ }^{+} \mathrm{H}_{2} \mathrm{O}_{2}$ (sulfuric acid + hydrogen peroxide). The inorganic $\mathrm{P}$ on resin, $\mathrm{HCl}$, and residual digestion extracts were determined by Murphy and Riley (1962) method, whereas $\mathrm{P}$ inorganic of alkaline extracts $\left(\mathrm{NaHCO}_{3}\right.$ and $\mathrm{NaOH}, 0.1$ and $\left.0.5 \mathrm{~mol} \mathrm{~L}^{-1}\right)$ were determined by Dick and Tabatabai's (1977) method. The organic fractions on alkaline extracts were obtained by its digestion with ammonium persulfate and diluted $\mathrm{H}_{2} \mathrm{SO}_{4}$, by autoclaving at $120{ }^{\circ} \mathrm{C}$ during $2 \mathrm{~h}$. Then, $\mathrm{P}$ contents were determined following Murphy and Riley's (1962) methodology and subtracted by the inorganic P 
result found on those fractions, which by calculation provides the organic P content. At the end, the $\mathrm{P}$ contents of each fraction were added to residual $\mathrm{P}$ in order to obtain the total $\mathrm{P}$ in the soil.

The data were submitted to analysis of variance (ANOVA) and means were compared by Scott-Knott $(P<0.05)$ test, using the statistics program Sisvar (Ferreira 2011).

\section{Results and Discussion}

The application of $\mathrm{P}$ sources, with and without filter cake, affected all $\mathrm{P}$ fractions in the soil (Tables 1 and 2), except residual P (Table 2), which was not influenced by treatments.

The P labile fraction extracted by resin was not affected by $\mathrm{P}$ sources (Table 1), and neither differed from control treatment. However, it showed isolated effect of filter cake, which the presence indicated greater contents of that $\mathrm{P}$ fraction compared to its absence. Brazilian laboratories conventionally use $\mathrm{P}$ determined by resin extractor to diagnose crops' nutrient availability; nevertheless, it corresponds to a small fraction of total $\mathrm{P}$ in the soil, as reported by Busato, Canellas, and Velloso (2005) in a study of Cambisoil cultivated with sugarcane. In the present study, triple superphosphate showed only $5 \%$ of resin $\mathrm{P}$ in the total $\mathrm{P}$; Bayóvar phosphate indicated 3\% and phosphate from Araxá $2 \%$. High rates of phosphate fertilizers (greater than crop requirement) increase the content of this $\mathrm{P}$ fraction; however, the application of low rates (crop requirement) does not affect this fraction's content (Zamuner, Picone, and Diez 2012). It is important to mention that the cultivated plant species modify P depletion's rate, as observed in Schoninger, Gatiboni,

\section{Table 1}

Soil phosphorus content $\left(\mathrm{mg} \mathrm{kg}^{-1}\right)$ extracted by anion exchange resin (P resin), sodium bicarbonate $\left(\mathrm{NaHCO}_{3}\right)$, and sodium hydroxide $\left(\mathrm{NaOH}, 0.1 \mathrm{~mol} \mathrm{~L}^{-1}\right)$ extractors on soil samples cultivated with sugarcane under phosphorus sources and filter cake fertilizations

\begin{tabular}{|c|c|c|c|c|c|}
\hline \multirow[b]{2}{*}{ P sources } & \multirow[b]{2}{*}{$P$ resin } & \multicolumn{2}{|c|}{$\mathrm{NaHCO}_{3}$} & \multicolumn{2}{|c|}{$\mathrm{NaOH}\left(0.1 \mathrm{~mol} \mathrm{~L}^{-1}\right)$} \\
\hline & & $\mathrm{Pi}$ & Po & $\mathrm{Pi}$ & Po \\
\hline Whitout P & 8.5 & $8.1 \mathrm{~b}$ & $9.5 \mathrm{~b}$ & $16.0 \mathrm{~b}$ & $1.6 \mathrm{~b}$ \\
\hline NP & 10.7 & $11.0 \mathrm{~b}$ & $14.4 \mathrm{a}$ & $17.8 \mathrm{~b}$ & $7.6 \mathrm{a}$ \\
\hline RNP & 10.3 & $12.9 \mathrm{~b}$ & $12.7 \mathrm{a}$ & $20.5 \mathrm{a}$ & $5.1 \mathrm{a}$ \\
\hline TSP & 13.3 & $17.1 \mathrm{a}$ & $11.4 \mathrm{a}$ & $24.4 \mathrm{a}$ & $4.1 \mathrm{~b}$ \\
\hline \multicolumn{6}{|c|}{ Filter cake (FC) } \\
\hline Presence & $15.2 \mathrm{a}$ & $15.8 \mathrm{a}$ & 11.8 & $23.7 \mathrm{a}$ & 3.9 \\
\hline Absence & $6.3 \mathrm{~b}$ & $8.7 \mathrm{~b}$ & 12.2 & $15.6 \mathrm{~b}$ & 5.3 \\
\hline \multicolumn{6}{|l|}{ F-test } \\
\hline $\mathrm{P}$ & $1.11 \mathrm{~ns}$ & $5.39 *$ & $3.98 * *$ & $6.58 * *$ & $6.45^{* *}$ \\
\hline $\mathrm{FC}$ & $22.26 * *$ & $19.17 * *$ & $0.15 \mathrm{~ns}$ & $32.88 * *$ & $2.18 \mathrm{~ns}$ \\
\hline $\mathrm{P} \times \mathrm{FC}$ & $1.46 \mathrm{~ns}$ & $1.03 \mathrm{~ns}$ & $0.75 \mathrm{~ns}$ & $0.80 \mathrm{~ns}$ & $0.19 \mathrm{~ns}$ \\
\hline CV (\%) & 43.12 & 32.40 & 21.35 & 17.73 & 52.61 \\
\hline
\end{tabular}

Notes. Means following different letters in columns differ from each other by Scott-Knott $(P<0.05){ }^{* *}, *$, and ns: significant at $1 \%$ and $5 \%$ of probability and no significance. $\mathrm{CV}$, coefficient of variance;

NP, natural phosphate from Araxá; RNP, reactive natural phosphate Bayóvar; TSP, triple superphosphate; Pi, inorganic phosphorus; Po, organic phosphorus. 
Table 2

Soil phosphorus content $\left(\mathrm{mg} \mathrm{kg}^{-1}\right)$ extracted by hydrochloric acid $\left(\mathrm{HCl} 1 \mathrm{~mol} \mathrm{~L}^{-1}\right)$ and sodium hydroxide $\left(\mathrm{NaOH}, 0.5 \mathrm{~mol} \mathrm{~L}^{-1}\right)$; residual phosphorus and total phosphorus of soil samples cultivated with sugarcane under phosphorus sources and filter cake fertilizations

\begin{tabular}{|c|c|c|c|c|c|}
\hline \multirow[b]{2}{*}{ P sources } & \multirow[b]{2}{*}{$\mathrm{P}(\mathrm{HCl})$} & \multicolumn{2}{|c|}{$\mathrm{NaOH}\left(0.5 \mathrm{~mol} \mathrm{~L}^{-1}\right)$} & \multirow[b]{2}{*}{ Residual P } & \multirow[b]{2}{*}{ Total P } \\
\hline & & $\mathrm{Pi}$ & Po & & \\
\hline Whitout P & $4.3 \mathrm{c}$ & $41.8 \mathrm{~b}$ & $2.7 \mathrm{~b}$ & 126.8 & $219.3 \mathrm{c}$ \\
\hline NP & $283.4 \mathrm{a}$ & $56.7 \mathrm{a}$ & $37.4 \mathrm{a}$ & 131.7 & $570.8 \mathrm{a}$ \\
\hline RNP & $43.7 \mathrm{~b}$ & $53.1 \mathrm{a}$ & $4.3 \mathrm{~b}$ & 146.3 & $309.0 \mathrm{~b}$ \\
\hline TSP & $5.3 \mathrm{c}$ & $38.6 \mathrm{~b}$ & $7.1 \mathrm{~b}$ & 137.9 & $259.2 \mathrm{c}$ \\
\hline \multicolumn{6}{|c|}{ Filter cake (FC) } \\
\hline Presence & $76.6 \mathrm{a}$ & 50.0 & 12.6 & 148.7 & 358.3 \\
\hline Absence & $91.8 \mathrm{~b}$ & 45.1 & 13.1 & 122.6 & 320.8 \\
\hline \multicolumn{6}{|l|}{ F-test } \\
\hline $\mathrm{P}$ & $633.5 * *$ & $4.18^{*}$ & $45.04 * *$ & $0.22 \mathrm{~ns}$ & $54.99 * *$ \\
\hline $\mathrm{FC}$ & $8.14 *$ & $1.28 \mathrm{~ns}$ & $0.05 \mathrm{~ns}$ & $2.11 \mathrm{~ns}$ & $3.07 \mathrm{~ns}$ \\
\hline $\mathrm{P} \times \mathrm{FC}$ & $12.1 * *$ & $0.64 \mathrm{~ns}$ & $0.30 \mathrm{~ns}$ & $0.17 \mathrm{~ns}$ & $0.64 \mathrm{~ns}$ \\
\hline CV $(\%)$ & 15.5 & 21.95 & 46.60 & 32.45 & 15.41 \\
\hline
\end{tabular}

Notes. Means following different letters in columns differ from each other by Scott-Knott $(P<0.05) .{ }^{* *}, *$, and ns: significant at $1 \%$ and $5 \%$ of probability and no significance. $\mathrm{CV}$, coefficient of variance; NP, natural phosphate from Araxá; RNP, reactive natural phosphate Bayóvar; TSP, triple superphosphate; Pi, inorganic phosphorus; Po, organic phosphorus.

and Ernani's (2012) study, which shows that grasses have greater P uptake capacity. Those results can explain the absence of effect on $\mathrm{P}$ labile fraction by the tested sources, as the soluble $\mathrm{P}$ rate applied was not high and the crop has high uptake capacity.

There was an isolated effect of $\mathrm{P}$ sources on inorganic and organic $\mathrm{P}$ fractions determined by sodium bicarbonate $\left(\mathrm{NaHCO}_{3}\right)$ extractor. The biggest inorganic $\mathrm{P}$ content was observed when triple superphosphate was applied, which was greater than all the other $\mathrm{P}$ sources. That $\mathrm{P}$ form is also classified as labile $\mathrm{P}$, demonstrating that triple superphosphate increases labile $\mathrm{P}$ fraction compared to the other sources. The filter cake also indicated effect on inorganic $\mathrm{P}$ fraction, as the fraction presented greater values when the compost is present. For the organic fraction extracted by $\mathrm{NaHCO}_{3}$, the control treatment presented lower $\mathrm{P}$ content than the other $\mathrm{P}$ sources, which was already expected. The absence of filter cake effect on organic fractions was not an expected result but might have occurred due to $\mathrm{P}$ mineralization on filter cake during the crop cycle.

The inorganic $\mathrm{P}$ fraction extracted by resin and the inorganic and organic fractions by $\mathrm{NaHCO}_{3}$ are considered as labile forms on Hedley fractionation (Table 1), which are the more available forms for plant uptake (Cross and Schlesinger 1995; Gatiboni et al. 2007). The present study did not detect effects of $\mathrm{P}$ sources on $\mathrm{P}$ labile fractions, in agreement with Santos et al. (2008), who studied different $P$ sources and type of applications during 3 years of corn cultivation. When the total $\mathrm{P}$ ( $\mathrm{P}$ organic $+\mathrm{P}$ inorganic) extracted by $\mathrm{NaHCO}_{3}$ was evaluated, it was observed that only one $\mathrm{P}$ fraction represented the lower amount of the total $\mathrm{P}$ in the soil, as triple superphosphate showed $11 \%$ of this fraction, phosphate Bayóvar $8 \%$, and phosphate from Araxá 4\%, resembling the control treatment, which showed $8 \%$. 
It is important to point that besides the reactive differences of $\mathrm{P}$ sources among the treatments, plant uptake and adsorption processes during the 22 months of applications might have levelled the availability of labile forms in all sources tested, as also stated by Santos et al. (2008) in corn cultivation. Because labile forms represent a small fraction of total $\mathrm{P}$ in the soil, isolated analysis of available $\mathrm{P}$, normally used in laboratory routines, might not be a great parameter to accurate interpretations of $\mathrm{P}$ content in the soil and its relationship to crop responses.

The determination of $\mathrm{P}$ fractions by the extractor sodium hydroxide $(\mathrm{NaOH}$, $0.1 \mathrm{~mol} \mathrm{~L}^{-1}$ ) were affected by $\mathrm{P}$ sources, as greater contents of inorganic $\mathrm{P}$ were detected on phosphate Bayóvar and triple superphosphate compared to phosphate from Araxá and absence of $\mathrm{P}$ (control). Filter cake increased inorganic $\mathrm{P}$ fractions in relation to its absence. The organic fraction showed greater contents in the presence of phosphates from Araxá and Bayóvar than in the presence of triple superphosphate and absence of $\mathrm{P}$, while filter cake did not demonstrate any effect. Conversely, absolutes values of organic $\mathrm{P}$ were pretty low in comparison to previous studies, which represented small amount on total $\mathrm{P}$. Gatiboni et al. (2007), studying soils grown with different plant species in the south of Brazil, found greater values of that $P$ fraction, which ranged from 46.6 to $115.8 \mathrm{mg} \mathrm{kg}^{-1}$ after applications of different rates of P. In addition, Pavinato, Merlin, and Rosolem (2009) found values ranging from 20 to $105 \mathrm{mg} \mathrm{kg}^{-1}$.

The inorganic and organic forms of $\mathrm{P}$ extracted by $\mathrm{NaOH} 0.1 \mathrm{~mol} \mathrm{~L}^{-1}$ are considered moderately labile and, in general, represent inorganic $\mathrm{P}$ bound to oxides and to silicate clays with intermediate binding energy, and organic P is considered as averagely labile form (Cross and Schlesinger 1995; Gatiboni et al. 2008). Because the fractions are classified as averagely labile, it will contribute to $\mathrm{P}$ availability to future plant uptake (Pavinato, Merlin, and Rosolem 2009). This research indicated $11 \%$ of total P, extracted by $\mathrm{NaOH} 0.1 \mathrm{~mol} \mathrm{~L}^{-1}$, when triple superphosphate was applied, $8 \%$ under phosphate Bayóvar and control treatments, and 4\% under phosphate from Araxá fertilization.

Different behavior was observed when hydrochloric acid $(\mathrm{HCl})$ was used as the extractor, which showed significant interaction among the factors (Table 2). In either presence or absence of the filter cake, phosphate from Araxá demonstrated greater content of $\mathrm{P}$, followed by phosphate Bayóvar, which were greater than triple superphosphate and control treatments (Table 3). This result was expected, as nonreactive natural phosphates have great amounts of stable calcium phosphate (apatite), which is solubilized on the extraction due to its medium acidification. It is important to state that the rate used was based on soluble P; therefore, it was applied high amounts of nonsoluble P under natural

Table 3

Soil phosphorus content $\left(\mathrm{mg} \mathrm{kg}^{-1}\right)$ extracted by hydrochloric acid $(\mathrm{HCl})$ of soil samples cultivated with sugarcane under phosphorus sources and filter cake fertilizations

\begin{tabular}{lccrrr}
\hline Parameter & Without P & Araxá & Bayóvar & TSP & F-test \\
\hline With filter cake & $5.9 \mathrm{aC}$ & $248.1 \mathrm{bA}$ & $47.1 \mathrm{aB}$ & $5.2 \mathrm{aC}$ & $237.1^{* *}$ \\
Without filter cake & $2.7 \mathrm{aC}$ & $318.8 \mathrm{aA}$ & $40.3 \mathrm{aB}$ & $5.3 \mathrm{aC}$ & 408.6 \\
F-test & $0.10 \mathrm{~ns}$ & $44.01^{* *}$ & $0.41 \mathrm{~ns}$ & $0.00 \mathrm{~ns}$ & \\
\hline
\end{tabular}

Notes. Means following different lowercase letters on columns and uppercase letters on lines differ from each other by Scott-Knott $(P<0.05) .{ }^{* *}, *$, and ns: significant at $1 \%$ and $5 \%$ of probability and no significance. 
phosphate treatments, especially on phosphate from Araxá but also with Bayóvar. According to the sources' data within filter cake treatment, only the phosphate from Araxá promoted a significant effect, which presented greater $\mathrm{P}$ content in filter cake absence.

Phosphorus extractions using $\mathrm{HCl}$ are related to $\mathrm{P}$ forms bound to $\mathrm{Ca}$ (Hedley, Stewart, and Chauhan 1982) and, according to Pavinato, Merlin, and Rosolem (2009), the results of this fraction observed in their study were low in relation to soil total $\mathrm{P}$, which allows the assumption of low compost levels in the soil, similar to the results presented in this study. On the other hand, Yu et al. (2006) stated that P fraction was responsible for $45-60 \%$ of total $\mathrm{P}$, in neutral and alkaline soils from Florida.

In the present work we found $2 \%$ of this fraction under triple superphosphate, $14 \%$ under phosphate Bayóvar, 50\% under phosphate from Araxá, and 2\% in the control treatment. This result demonstrates that the P found on triple superphosphate was almost not found in this fraction, as the result was similar to the control. The high percent of this fraction on phosphate from Araxá is explained by the predominance of apatite on the source, as previous mentioned. It is relevant to cite the effect of filter cake on phosphate from Araxá, which solubilizes part of the nonsoluble $\mathrm{P}$, as it had less $\mathrm{P}$ bound to $\mathrm{Ca}$ in comparison to the absence of filter cake treatment.

Among the $\mathrm{P}$ fractions determined by $\mathrm{NaOH} 0.5 \mathrm{~mol} \mathrm{~L}^{-1}$ extractor (Table 2), inorganic $\mathrm{P}$ was greater in phosphate from Araxá and Bayóvar phosphate applications, overcoming triple superphosphate and control treatment. The smallest value of inorganic $\mathrm{P}$ on this fraction under triple superphosphate might have occurred because that source keeps its $\mathrm{P}$ as a soluble forms of soil fraction, which were determined on previous extractions. Upon the organic P with this extractor, greater value was observed on phosphate from Araxá application, which was greater than all others. Possibly, the phosphates present on phosphate from Araxá as low solubility forms were solubilized after the acidification promoted by $\mathrm{HCl}$ extraction, as well as after the digestion with persulfate and diluted $\mathrm{H}_{2} \mathrm{SO}_{4}$, which indicates a possible error in the classification of that fraction as an organic one, as it would be stable calcium phosphates that were broken after acidification and not measured on the previous extraction.

The filter cake did not show any effect on $\mathrm{P}$ fractions using $\mathrm{NaOH} 0.5 \mathrm{~mol} \mathrm{~L}^{-1}$, similar to previous results that studied organic residue (pig slurry) application (Gatiboni et al. 2008). Regarding the percentage of those fractions on total soil $\mathrm{P}$, organic $\mathrm{P}+$ inorganic P extracted by $\mathrm{NaOH} 0.5 \mathrm{~mol} \mathrm{~L}^{-1}$ presented $18 \%$ under triple superphosphate, $19 \%$ under phosphate Bayóvar, and 16\% under phosphate from Araxá, which are lower values than the $20 \%$ observed on control treatment.

After soil $\mathrm{P}$ application, there is an increasing trend in inorganic labile and moderately labile fractions (Zhang et al. 2004; Gatiboni et al. 2007), which are responsible to replace P in the soil solution. This fact was also observed in the present study, as the control treatment presented lower content of these fractions, excepted on resin, which did not differ from it.

The studied sources did not showed effects on residual $\mathrm{P}$, as it indicated $53 \%$ of this fraction when triple superphosphate was used, $47 \%$ with Bayóvar phosphate, and $23 \%$ on phosphate from Araxá application, compared to $58 \%$ of the control treatment. Therefore, it can be stated that, in general, residual $\mathrm{P}$ represents the main percentage of total $\mathrm{P}$ in the soil, except on phosphate from Araxá treatment, in which the total $\mathrm{P}$ applied was too high. It indicates that the main part of $\mathrm{P}$ is found as forms with high binding energy to soil colloids, as observed by Conte (2001) in soil samples from the south of Brazil. The results is also in agreement with Gonçalves and Meurer (2009) and Schmitt et al. (2013), who related that many soils from the south of Brazil, including some that had phosphate fertilization historic, present the $\mathrm{P}$ residual fraction as the main fraction of soil total $\mathrm{P}$. 
The residual fraction of $\mathrm{P}$ fractionation, obtained by acidic soil digestion, is constituted by the $\mathrm{P}$ that was not extracted by the selected extractors of Hedley fractionation, and showed as organic and inorganic recalcitrant $P$ forms (Gatiboni et al. 2007; Santos et al. 2008). Gatiboni et al. (2007), in a 6-year phosphate fertilization study, did not observed increase on this fraction of soil, which indicates that the $\mathrm{P}$ added is preferably accumulated as greater labile fractions. These authors stated that even on $\mathrm{P}$ deficiency systems, plant uptake causes a riffle effect of $\mathrm{P}$ labile replacement, first by intermediate labile forms and then by low labile forms.

The total $\mathrm{P}$ in the soil, obtained by the sum of fractions of each extractor, was greater on phosphate from Araxá, followed by Bayóvar phosphate, and both values were greater than triple superphosphate and control treatment (Table 2). In addition, the P rate was calculated in a soluble $\mathrm{P}$ base, as already mentioned on $\mathrm{P}$ extracted by $\mathrm{HCl}$. In this way, lower solubility forms receive greater total $\mathrm{P}$ rates of fertilizer. The filter cake did not demonstrate an effect on this fraction.

In general, there were no observed significant interactions between $\mathrm{P}$ sources and filter cake; however, the filter cake use (isolated factor) increases most of labile fraction of the soil, which can be explained by the content of $\mathrm{P}$ in this residue $\left(9.2 \mathrm{~g} \mathrm{~kg}^{-1}\right.$ of $\left.\mathrm{P}\right)$. Several pieces of information about the increment on phosphate fertilization's efficiency when it is associated with organic composts are present in the literature (Mkhabela and Warman 2005; Ohno et al. 2005; Garg and Bahl 2008), but synergic effects can also occur, as organic composts might act as a maintenance factor on the increment of labile forms in the soil, via competition (Pavinato, Merlin, and Rosolem 2009).

\section{Conclusions}

After 22 months of phosphate sources application, the greatest percentage of $\mathrm{P}$ is found as nonlabile $\mathrm{P}$ fractions, regardless of filter cake application.

The use of low solubility sources, such as natural phosphate from Araxá, in association with filter cake has promoted greater solubility of $\mathrm{P}$ bound to $\mathrm{Ca}$, which can enhance the crop uses.

Filter cake increases most of labile and moderately labile inorganic $\mathrm{P}$ forms in the soil (resin, $\mathrm{NaHCO}_{3}$, and $\mathrm{NaOH}, 0.1 \mathrm{~mol} \mathrm{~L}{ }^{-1}$ ), which characterizes the importance of this source to sugarcane nutrient supply.

\section{Funding}

G.C. is supported by CNPq through a postdoctoral scholarship.

\section{References}

Almeida Jr., A. B., C. W. A. Nascimento, M. F. Sobral, F. B. V. Silva, and W. A. Gomes. 2011. Fertilidade do solo e absorção de nutrientes em cana-de-açúcar fertilizada com torta de filtro (Soil fertility and nutrient absorption in sugarcane fertilized with filter cake). Revista Brasileira de Engenharia Agrícola e Ambiental 15:1004-13. doi:10.1590/S1415-436620 11001000003.

Ayaga, G., A. Todd, and P. C. Brookes. 2006. Enhanced biological cycling of phosphorus increases its availability to crops in low-input sub-Saharan farming systems. Soil Biology and Biochemistry 38:81-90. doi:10.1016/j.soilbio.2005.04.019.

Bataglia, O. C., A. M. C. Furlani, J. P. F. Teixeira, P. R. Furlani, and J. R. Gallo. 1983. Métodos de análise química de plantas. Boletim Técnico 78:49. 
Biswas, D. R., and G. Narayanasamy. 2006. Rock phosphate-enriched compost: An approach to improve low-grade Indian rock phosphate. Bioresource Technology 97:2243-51. doi:10.1016/j. biortech.2006.02.004.

Busato, J. G., L. P. Canellas, and A. C. X. Velloso. 2005. Fósforo num Cambissolo cultivado com cana-de-açúcar por longo tempo [Phosphorus in an Inceptsoil under long-term sugarcane, I: Sequential fractionation]. Revista Brasileira de Ciência do Solo 29:935-44. doi:10.1590/S010006832005000600011.

Condron, L. M., K. M. Goh, and R. H. Newman. 1985. Nature and distribution of soil phosphorus as revealed by a sequential extraction method followed by 31P nuclear magnetic resonance analysis. European Journal of Soil Science 36:199-207. doi:10.1111/ejs.1985.36.issue-2.

Conte, E. 2001. Atividade de fosfatase ácida e formas de acumulação de fosfato em solo no sistema plantio direto. Porto Alegre, Universidade Federal do Rio Grande do Sul. 65p. (Dissertação de Mestrado).

Cross, A. F., and W. H. Schlesinger. 1995. A literature review and evaluation of the Hedley fractionation: Applications to the biogeochemical cycle of soil phosphorus in natural ecosystems. Geoderma 64:197-214. doi:10.1016/0016-7061(94)00023-4.

Dick, W. A., and M. A. Tabatabai. 1977. Determination of orthophosphate in aqueous solutions containing labile organic and inorganic phosphorus compounds. Journal of Environment Quality 6:82-85. doi:10.2134/jeq1977.00472425000600010018x.

Ferreira, D. F. 2011. Sisvar: A computer statistical analysis system. Ciência e Agrotecnologia 35:1039-42.

Garg, S., and G. S. Bahl. 2008. Phosphorus availability to maize as influenced by organic manures and fertilizer P associated phosphatase activity in soils. Bioresource Technology 99:5773-77. doi:10.1016/j.biortech.2007.10.063.

Gatiboni, L. C., G. Brunetto, J. Kaminski, D. S. Rheinheimer, C. A. Ceretta, and C. J. Basso. 2008. Formas de fósforo no solo após sucessivas adições de dejeto líquido de suínos em pastagem natural [Phosphorus forms in the soil after successive additions of pig slurry on natural pasture]. Revista Brasileira de Ciência do Solo 32:1753-61. doi:10.1590/S0100-06832008000400040.

Gatiboni, L. C., J. Kaminski, D. S. Rheinheimer, and J. P. C. Flores. 2007. Biodisponibilidade de formas de fósforo acumuladas em solo sob sistema plantio direto [Bioavailability of phosphorus forms accumulated in soil under no-till]. Revista Brasileira de Ciência do Solo 31:691-99. doi:10.1590/S0100-06832007000400010.

Gichangi, E. M., P. N. S. Mnkeni, and P. C. Brookes. 2009. Effects of goat manure and inorganic phosphate addition on soil inorganic and microbial biomass phosphorus fractions under laboratory incubation conditions. Soil Science and Plant Nutrition 55:764-71. doi:10.1111/j.17470765.2009.00415.x.

Gikonyo, E. W., A. R. Zaharah, M. M. Hanafi, and A. R. Anuar. 2008. Evaluation of phosphorus pools and fractions in an acid tropical soil recapitalized with different phosphorus sources. Communications in Soil Science and Plant Analysis 39:1385-405. doi:10.1080/ 00103620802004151.

Gonçalves, G. K., and E. J. Meurer. 2009. Frações de fósforo no solo e sua relação com a absorção pelas plantas de arroz irrigado por alagamento em solos do Rio Grande do Sul [Phosphorus fractions in soil and its relation to plant uptake of rice by flooding in the Rio Grande soils]. Revista Brasileira de Ciência do Solo 33:357-62. doi:10.1590/S0100-06832009000200013.

Hedley, M. J., J. W. B. Stewart, and B. S. Chauhan. 1982. Changes in inorganic and organic soil phosphorus fractions induced by cultivation practices and by laboratory incubations. Soil Science Society of America Journal 46:970-76. doi:10.2136/sssaj1982.036159950046000 $50017 \mathrm{x}$.

Khan, K. S., and R. G. Joergensen. 2009. Changes in microbial biomass and P fractions in biogenic household waste compost amended with inorganic P fertilizers. Bioresource Technology 100:303-09. doi:10.1016/j.biortech.2008.06.002. 
Linquist, B. A., M. D. Ruark, and J. E. Hill. 2011. Soil order and management practices control soil phosphorus fractions in managed wetland ecosystems. Nutrient Cycling in Agroecosystems 90:51-62. doi:10.1007/s10705-010-9411-3.

Meena, S. 2010. Effect of different sources of phosphorus on yield and availability of phosphorus in maize-sunflower sequence in a Typic Haplustalf assessment using radio tracer technique. Journal of Plant Nutrition 33:1229-35. doi:10.1080/01904161003765752.

Mkhabela, M. S., and P. R. Warman. 2005. The influence of municipal solid waste compost on yield, soil phosphorus availability, and uptake by two vegetable crops grown in a Pugwash sand loam soil in Neva Scotia. Agriculture, Ecosystems \& Environment 106:57-67. doi:10.1016/j. agee.2004.07.014.

Murphy, J., and J. P. Riley. 1962. A modified single solution method for the determination of phosphate in natural waters. Analytica Chimica Acta 27:31-36. doi:10.1016/S0003-2670(00)88444-5.

Negassa, W., and P. Leinweber. 2009. How does the Hedley sequential phosphorus fractionation reflect impacts of land use and management on soil phosphorus? A review. Journal of Plant Nutrition and Soil Science 172:305-25. doi:10.1002/jpln.v172:3. 2009.

Ohno, T., T. S. Griffin, M. Liebman, and G. A. Porter. 2005. Chemical characterization of soil phosphorus and organic matter in different cropping system in Maine, USA. Agriculture, Ecosystems \& Environment 105:625-34. doi:10.1016/j.agee.2004.08.001.

Pavinato, P. S., A. Merlin, and C. A. Rosolem. 2009. Phosphorus fractions in Brazilian Cerrado soils as affected by tillage. Soil and Tillage Research 105:149-55. doi:10.1016/j.still.2009.07.001.

Raij, B. V., J. C. Andrade, H. Cantarella, and J. A. Quaggio. 2001. Análise química para avaliação da fertilidade dos solos tropicais [Chemical analysis to evaluate the fertility of tropical soils]. Ed. Raij, B. V., J. C. Andrade, H. Cantarella, and J. A. Quaggio. Campinas: Instituto Agronômico. 285p.

Raij, B. V., and H. Cantarella. 1997. Outras culturas industriais. In. Recomendações de adubação e calagem para o estado de São Paulo, 2nd ed., ed. B. V. Raij, H. Cantarella, J. A. Quaggio, and A. M. C. Furlani, 233-39. Campinas São Paulo, Brazil: Instituto Agronômico.

Santos, H. G., P. K. T. Jacomine, L. H. C. Anjos, V. A. Oliveira, J. F. Lumbreras, M. R. Coelho, J. A. Almeida, T. J. F. Cunha, and J. B. Oliveira. Eds. 2013. Sistema brasileiro de classificação de solos [Brazillian system of soil classification], 3rd ed. Rio de Janeiro: Embrapa Solos.

Santos, J. Z. L., A. E. Furtini Neto, Á. V. Resende, N. Curi, L. F. Carneiro, and S. E. V. G. A. Costa. 2008. Frações de fósforo em solo adubado com fosfatos em diferentes modos de aplicação e cultivado com milho [Phosphorus fractions in soil fertilized with phosphate in different modes of application and planted with corn]. Revista Brasileira de Ciência do Solo 32:705-14. doi:10.1590/S0100-06832008000200025.

Schmitt, D. E., J. J. Comin, L. C. Gatiboni, T. Tiecher, F. Lorensini, G. W. B. Melo, E. Girotto, R. Guardini, J. Heinzen, and G. Brunetto. 2013. Phosphorus fractions in sandy soils of vineyards in southern Brazil. Revista Brasileira de Ciência do Solo 37:472-81. doi:10.1590/S010006832013000200018.

Schmitt, J. P., S. W. Buol, and E. J. Kamprath. 1996. Soil phosphorus dynamics during seventeen years of continuous cultivation: Fractionation analyses. Soil Science Society of America Journal 60:1168-72. doi:10.2136/sssaj1996.03615995006000040030x.

Schoninger, E. L., L. C. Gatiboni, and P. R. Ernani. 2012. Rhizosphere pH and phosphorus forms in an Oxisol cultivated with soybean, brachiaria grass, millet, and sorghum. Scientia Agricola 69:259-64. doi:10.1590/S0103-90162012000400004.

Silva, F. C., and B. V. Raij. 1996. Avaliação da disponibilidade de fósforo por diversos extratores em amostras de solos cultivados com cana-de-açúcar. Revista Brasileira de Ciência do Solo 20:83-90.

Souza Jr., R. F., F. H. T. Oliveira, H. C. Santos, F. J. Freire, and J. A. Arruda. 2012. Frações de fósforo inorgânico do solo e suas correlações com o fósforo quantificado por extratores e pelo Milho. Revista Brasileira de Ciência do Solo 36:159-69. doi:10.1590/S0100-068320 12000100017. 
Tokura, A. M., A. E. Furtini Neto, F. C. Carneiro, N. Curi, J. Z. L. Santos, and A. A. Alovisi. 2011. Dinâmica das formas de fósforo em solos de textura e mineralogia contrastantes cultivados com arroz. Acta Scientiarum Agronomy 33:171-79. doi:10.4025/actasciagron.v33i1.1435.

Yu, S., Z. L. He, P. J. Stoffella, D. V. Calvert, X. E. Yang, D. J. Banks, and V. C. Baligan. 2006. Surface runoff phosphorus (P) loss in relation to phosphates activity and soil $\mathrm{P}$ fractions in Florida sandy soils under citrus production. Soil Biology and Biochemistry 38:619-28. doi:10.1016/j.soilbio.2005.02.040.

Zamuner, E. C., L. I. Picone, and A. B. Diez. 2012. Effect of long-term phosphorus fertilization on soil phosphorus fractions. Spanish Journal of Soil Science 2:50-61.

Zhang, T. Q., A. F. Mackenzie, B. C. Liang, and C. F. Drury. 2004. Soil test phosphorus and phosphorus fractions with long-term phosphorus addition and depletion. Soil Science Society of America Journal 68:519-28. doi:10.2136/sssaj2004.5190. 